\title{
Article
}

http://dx.doi.org/10.11646/phytotaxa.226.2.4

\section{New species in Diplusodon (Lythraceae) from Brazil}

\author{
TACIANA B. CAVALCANTI ${ }^{1}$
}

Embrapa Genetic Resources and Biotechnology, Parque Estação Ecológica, Final W5 Norte, CP 02372, CEP 70.770-917, Brasília, DF, Brazil.taciana.cavalcanti@embrapa.br

\begin{abstract}
Six new Diplusodon species from Brazil are described, illustrated and compared with related species. They include Diplusodon rotatus, a novelty from savannas with rocky soils of Maranhão state, D. stellatus, D. venosus and D. vittatus from the mountains of Goiás state, D. verruculosus from the campos rupestres mountains of Minas Gerais state, and D. xiphodon from campos rupestres mountains of Bahia.
\end{abstract}

Key words: Brazilian savanna, Cerrado biome, endemism

\section{Introduction}

The genus Diplusodon Pohl (1827: 150) is the second largest genus in the Lythraceae, with 102 species occurring in Brazilian savannas (Cerrado biome), including two taxa in Bolivian savannas (Cavalcanti \& Graham 2005; Cavalcanti 2015). They are shrubs or subshrubs with showy, 6-merous, actinomorphic flowers and floral tubes on which the sepals are alternate with conspicuous epicalyx segments. Their capsular fruits have a bipartite placenta with lunate septa, unique in the family, and the seeds are winged.

In Diplusodon there is a high degree of narrow endemism among the species restricted to specialized microhabitats, in mountains at 1,000-1,600 m elev. with rough topography, where they grow on sandy and rocky soils among rocky outcrops and slopes. The species are isolated by geographical barriers and climate in campos rupestres, the mountains of the east and midwest of the country (Cavalcanti 2007; Cavalcanti \& Noronha 2009; Cavalcanti et al. 2013). Species isolation has been a significant factor in production of morphological novelties within the group (Cavalcanti 1995, Inglis et al. 2009).

Many species of Diplusodon are threatened because of their restricted distributions. The species occurring in flat areas of the Cerrado biome are especially threatened because of exploitation for agriculture and pasture. The cerrado vegetation areas are disappearing rapidly, and the conservation units established within the Cerrado biome are few and small.

Six new species are described here as part of an ongoing effort to revise the genus. They added to other recent additions to Diplusodon discovered in the Brazilian flora (Cavalcanti 2011).

\section{Materials and methods}

The specimens were identified based on the generic monograph of Koehne (1903) and a study by Lourteig (1989) that formed the basis of all following taxonomic work on the genus. Extensive field work has been conducted during the ongoing revision of the genus, through which about $90 \%$ of the Diplusodon species were collected and observed in nature. 
1. Diplusodon rotatus T.B. Cavalc., $s p$. nov.

Type:-BRAZIL. Maranhão: Balsas, Lote 19, na descida da escarpa-Agrovila Nova de Carli, 841'39”S, 4645’45”W, 4 August 1998 (fl.), Oliveira et al. 1245 (holotype CEN!, isotypes CEN!, HEPH!). Figures 1, 2.

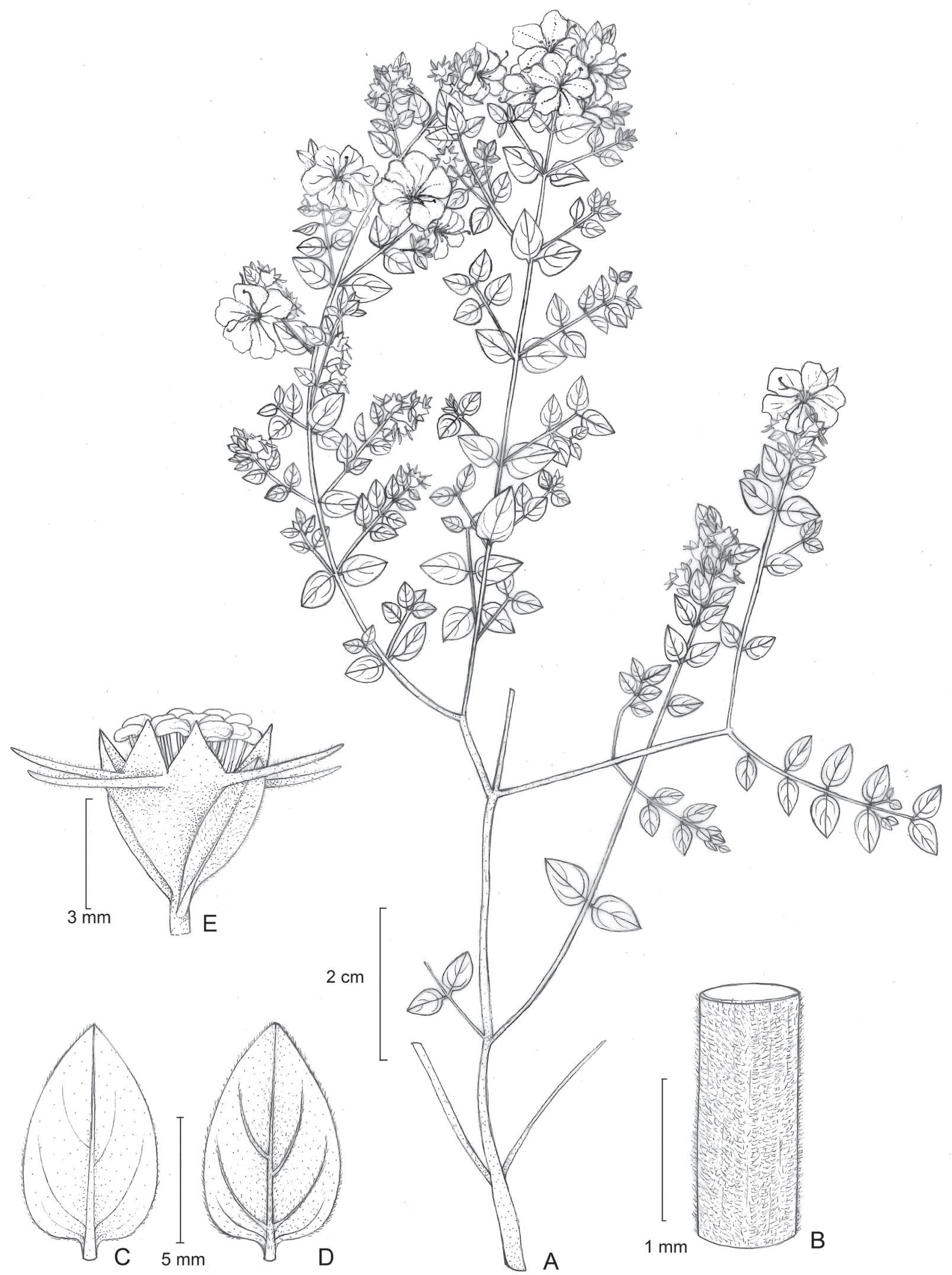

FIGURE 1. Diplusodon rotatus (A-E from Oliveira et al. 1245). A, branch with inflorescences. B, detail of a branch. C, leaf, adaxial surface. D, leaf, abaxial surface. E, flower with prophylls, without petals. 
Species characterized by shrubby habit with minute indumentum throughout the plant, vegetative leaf different from the bracts, oval bracts with domatia, little flowers with 12 stamens, epicalyx segments evident, longer than sepals, spread horizontally and prophylls positioned on the upper third of the pedicel.

Shrubs 1-1.5 $\mathrm{m}$ tall. Branches lax, the uppermost delicate, rust to wine-colored, cylindrical compressed, unwinged, minutely pubescent, internodes $12-16 \mathrm{~cm}$ long. Leaves light green, decussate, not imbricate, suberect, chartaceous, petiolate, not discolorous, light green when dry, acrodromous-basal-supranumerary; petiole 1.5-2 mm long, thick; blades 20-35 × 12-19 mm, oblong to ovate, base retuse, apex obtuse, acuminate, margin plane to slightly subrevolute, ciliate with short trichomes, adaxial surface minutely pubescent to glabrescent, abaxial surface minutely pubescent; veins 2 or 3 on each side of the midvein, 2 departing near the base of the midvein, sulcate on the adaxial surface, slightly prominent on the abaxial surface; domatia absent. Synflorescence frondose, pleiobotryum type, branches rust colored, thin, delicate, lax; principal florescence truncate; paraclades of the first and second order $15-30 \mathrm{~cm}$ long; paraclades of the third order 4-7 cm long; bracts oval to elliptic, spreading to suberect, base retuse to slightly subcordate, margin plane to slightly subrevolute, pubescent, ciliate with short trichomes, apex obtuse, slightly acuminate, veins 2 or 3 on each side of the midvein, with domatia; flowers pedicelate, hypopodium ca. $1.5 \mathrm{~mm}$ long, epipodium ca. 0.5 $\mathrm{mm}$ long; prophylls 4-4.6 $\times 1.2-2 \mathrm{~mm}$, inserted on the upper third of the pedicel, surpassing the apex of the floral tube, narrowly elliptic, unkeeled, base attenuate, apex acute, margin plane, minutely pubescent; floral tube $4.2-4.5 \mathrm{~mm}$ long, delicate, funnel-shaped, with minute trichomes; sepals 2-2.5 $\mathrm{mm}$ long, triangular, not caudate, not deflexed, with minute trichomes; epicalyx segments 4-4.1 mm long, fine, cylindrical, spreading, longer than the sepals, with minute, spiky trichomes; corolla 2-2.5 cm in diam., rose, petals 9-10 $\times 5-7 \mathrm{~mm}$, obovate, apex obtuse; stamens 12 , free portion of the filaments ca. $5 \mathrm{~mm}$ long, slightly exserted; ovary $2-2.4 \times 2.2-2.9 \mathrm{~mm}$, obovate, glabrous, style 7-8 $\mathrm{mm}$ long, ovules 10-12. Capsules 3.6-4 × 3.5-4 mm, globose to oblong, glabrous; seeds 3 or 4, 2.5-2.9 × 2-2.1 mm.

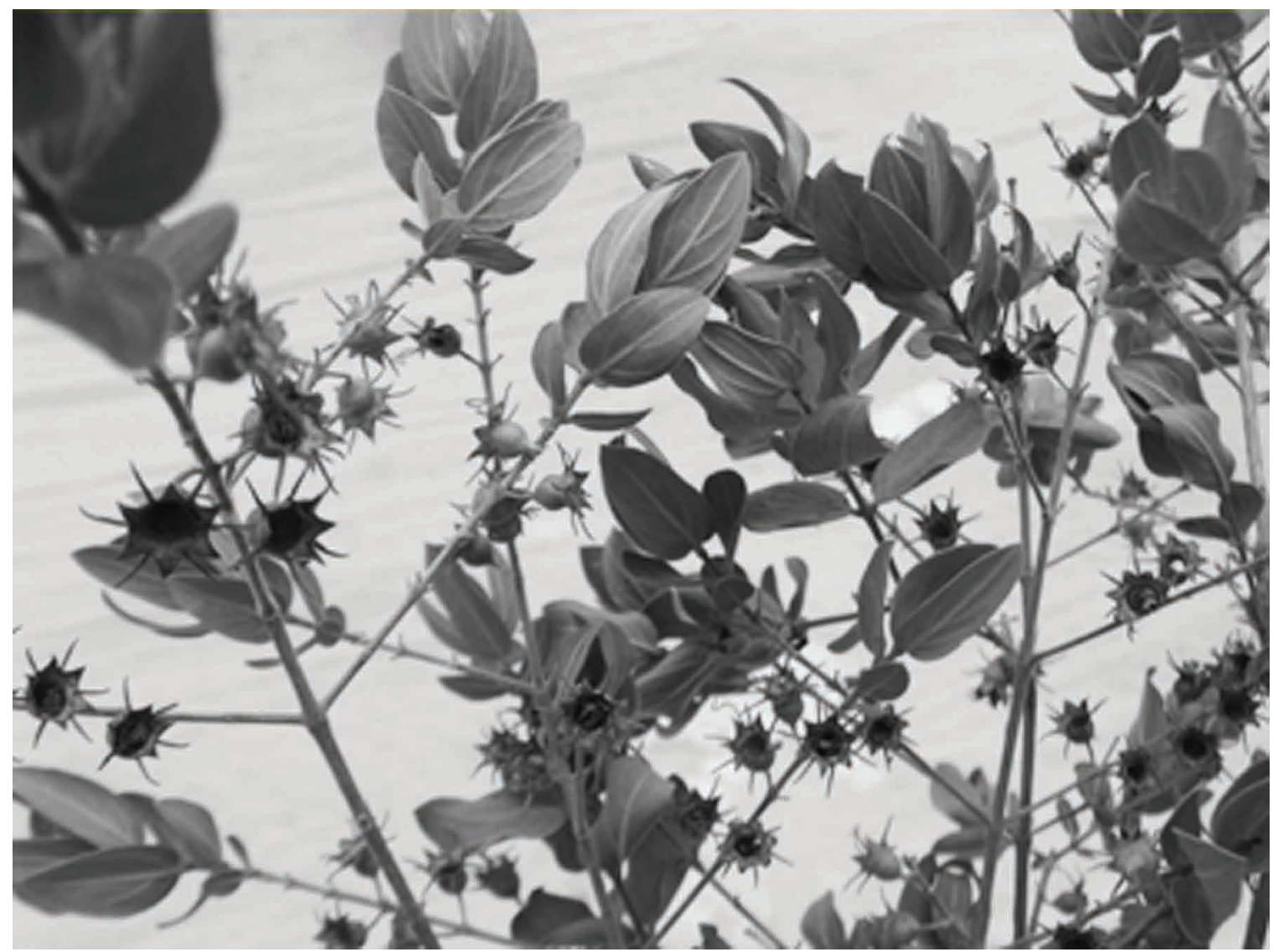

FIGURE 2. Diplusodon rotatus. Branch with fruits (author of the photograph: T.B. Cavalcanti; voucher Cavalcanti \& Pereira-Silva $3780)$.

Distribution and ecology:-Diplusodon rotatus is a rare species found in cerrado, sensu stricto, with rocky soil, at 200-447 m. Flowers from June to August; fruits October to January.

Etimology:- Specific epithet related to epicalyx segments horizontally spreading around the floral tube.

Paratypes:-BRAZIL. Maranhão: Carolina, BR 010-Balneário, ca. 500m da pista em estrada de terra, $7^{\circ} 1$ '3"S, 47²7’27'W, 19 October 2013 (fr.), Cavalcanti \& Pereira-Silva 3780 (CEN!, MO!, NY!, UFMA!, W!); Carolina, estrada 
BR 010-Balneário Encontro das Águas, km 1, área de influência indireta, 7²1’3” S, 47²7’46” W, 19 January 2010 (fr.), Pereira-Silva \& Moreira 14965 (CEN!, HUEFS!, SP!).

Comments:-Diplusodon rotatus is a tall shrub which loses its vegetative leaves during flowering. In this case, the vegetative leaves are much larger than the bracts, and are not present on the plant at the same time. The vegetative leaves in D. rotatus are oblong and without domatia, while the bracts are oval with domatia, which can cause problems of identification. Diplusodon rotatus is characterized by the presence of minute indumentum throughout the plant, flowers with 12 stamens, epicalyx segments evident, strongly spreading and prophylls positioned on the upper third of the pedicel. The inflorescence is delicate with small flowers.

\section{Diplusodon stellatus T.B. Cavalc., $s p$. nov.}

Type:-BRAZIL. Goiás: Parque Nacional da Chapada dos Veadeiros, estrada para Colinas, a 34 km do entroncamento da GO, 15 August 1990 (fl.), Cavalcanti et al. 684, (holotype CEN!, isotypes MO!, NY!, SPF!). Figure 3.

Species characterized by dense stellate trichomes forming tufts throughout the plant, narrow leaves with revolute margin, flowers with 12 stamens and epicalyx segments longer than sepals.

Subshrubs $0.4-1 \mathrm{~m}$ tall, with a xylopodium. Upper branches cylindrical, lax, unwinged, covered by stellate trichomes forming tufts, internodes $0.8-3 \mathrm{~cm}$ long. Leaves decussate, not imbricate, suberect, coriaceous, petiolate, slightly discolorous, eucamptodromous; petiole 1.5-2 mm long; blades 15-35 × 1.5-4(-6) mm, narrow-lanceolate or narrow-elliptic to linear, base acute, apex acute, margin revolute, adaxial surface olive-green, covered by dense stellate trichomes forming tufts; abaxial surface canescent, covered by dense stellate trichomes in tufts, veins 1 or 2 on each side of the midvein, prominent on the abaxial surface; domatia absent. Synflorescence frondose, diplobotryum spiciform to pleiobotryum spiciform type, lax; accessory branches absent, principal florescence 3-5 mm long, botryum spiciform type, paraclades 5-17 mm long; bracts similar to the vegetative leaves, except diminishing in size toward the apex of the branch, 10-17 × 1.5-3 mm wide, linear, margin revolute; flowers subsessile, hypopodium ca. $0.5 \mathrm{~mm}$ long, epipodium ca. 0-0.3 mm long; prophylls 3.1-3.2 × 1-1.1 mm, slightly surpassing the middle of the floral tube, narrow-oblong, with strongly prominent midrib, base retuse, apex acute, margin plane; floral tube 4-4.5 mm long, canescent, funnel-shaped, covered by dense stellate trichomes forming tufts; sepals $1.5-1.6 \mathrm{~mm}$ long, rose, triangular, not deflexed, not caudate, not ciliate, covered by dense stellate trichomes forming tufts; epicalyx segments 3-4 mm long, rose, cylindrical, erect, exceeding the sepals $2-3 \mathrm{~mm}$, covered by dense stellate trichomes forming tufts; corolla $3.5-4 \mathrm{~cm}$ in diam, rose-magenta to lilac, petals $21-22 \times 6-10 \mathrm{~mm}$, obovate, apex obtuse; stamens 12 , free portion of the filaments ca. $5.5 \mathrm{~mm}$ long, rose, exserted $2-2.1 \mathrm{~mm}$, surpassing the sepals ca. $1 \mathrm{~mm}$; ovary ca. $1.8 \times 1.9 \mathrm{~mm}$, obovate-depressed, glabrous, style 10-11 mm long, rose, ovules 10. Capsules 2.5-2.8 $\times 2.6-2.9 \mathrm{~mm}$, oblong, glabrous; seeds ca. $5,1.9-2 \times 1.2-1.5 \mathrm{~mm}$.

Distribution and ecology:-Diplusodon stellatus occurs on sandy soils of campos rupestres, campos sujos, campos limpos and cerrado with rocky outcrops on the Chapada dos Veadeiros, Goiás, at 880-1,200 m. Flowers from April to August; fruits observed in January.

Etimology:- Specific epithet related to the presence of stellate trichomes on the whole plant.

Paratypes:-BRAZIL. Goiás: Alto Paraíso de Goiás, 15 May 1986 (fl.), Toledo et al. 113 (IBGE!); Alto Paraíso de Goiás, 14 June 1993 (fr.), Hatschbach et al. 59523 (BR!, MBM, MO!); Alto Paraíso de Goiás, Parque Nacional da

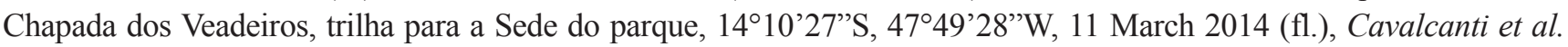
3820 (CEN!); Alto Paraíso de Goiás, Parque Nacional da Chapada dos Veadeiros, estrada para Colinas, a 34 km do entroncamento da GO, 14¹0'0'S, 4747'29'W, 15 August 1990 (fr.), Cavalcanti et al. 682 (CEN!, SPF!); Alto Paraíso de Goiás, povoado São Jorge, 20 May 2003 (fl.), Pastore \& Suganuma 651 (CEN!); Alto Paraíso de Goiás, estrada Alto Paraíso de Goiás-São Jorge, próximo à casa do IBAMA, 29 January 2003 (fr.), Cavalcanti et al. 3162 (CEN!, MO!); Alto Paraíso de Goiás, São Jorge, caminho para mirante, 11 April 2004 (fl.), Rodrigues \& Chesini 191 (CEN!); Alto Paraíso de Goiás, estrada Alto Paraíso de Goiás-Colinas do Sul, a 1 km de São Jorge, 2 June 1999 (fr.), Cavalcanti \& Silva 2508 (CEN!, MO!, SPF!); Alto Paraíso de Goiás, margem da estrada entre Alto Paraíso e São Jorge, 146'13" S, 47²8'50" W, 5 April 2014 (fl.), Faria, Jr. et al. 3959 (CEN!, UB!); Alto Paraíso de Goiás, Chapada dos Veadeiros, 28 July 1985 (fl., fr.), Romaniuc-Neto \& Sajo 380 (SP!); Alto Paraíso de Goiás, Chapada dos Veadeiros, 148' S, 47³1' W, 19 May 1987 (fl.), Menezes 1209 (K!, SPF!); Cavalcante, GO-327, Colinas do Sul-GO-118, 14¹0’ S, 47²9’ W, 8 March 1989 (fl.), Cavalcanti et al. 394 (CEN!, IBGE!, NY!, K!, SP!). Colinas do Sul, estrada de terra em direção a Alto Paraíso de Goiás, 27 April 2009 (fl.), Cardoso 2570 (HUEFS!). 


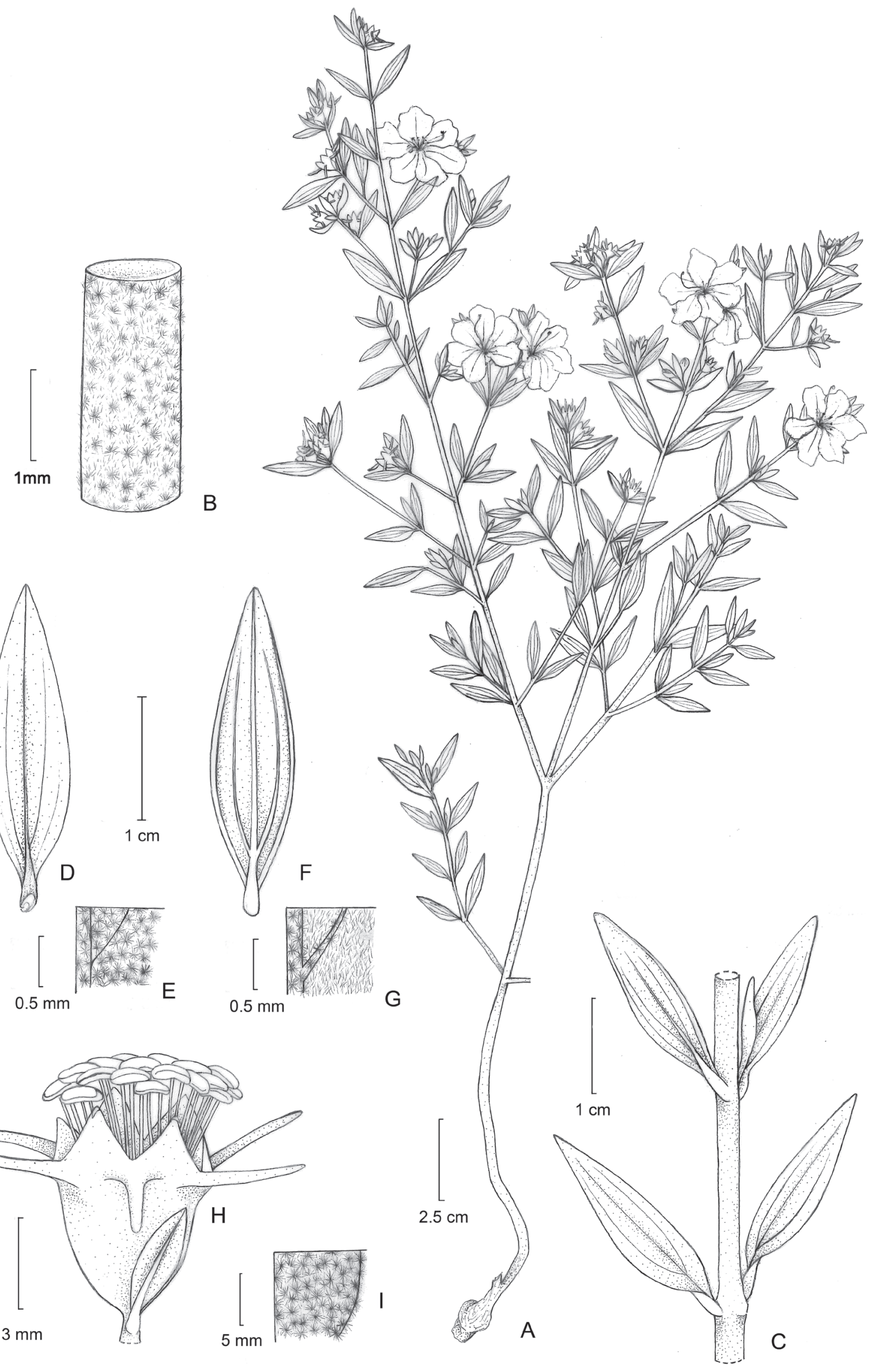

FIGURE 3. Diplusodon stellatus. (A-I from Cavalcanti et al. 684). A, habit. B, detail of a branch. C, section of an internode. D. leaf, adaxial surface. E, detail of the leaf adaxial surface indumentum. F. leaf, abaxial surface. G, detail of the leaf abaxial surface indumentum. H. flower with prophyll, without petals. I. detail of the floral tube indumentum. 
Comments:-Diplusodon stellatus is characterized by the dense tufts of stellate trichomes close to one another covering the entire plant that confers a flaky aspect to the surface. It is also characterized by its narrow-lanceolate or narrow-elliptic to linear leaves with revolute margin, androecium with 12 stamens and epicalyx segments with 3.1-3.5 $\mathrm{mm}$ long. The species resembles D. rosmarinifolius A.Saint-Hilaire (1833: 119) because of its stellate trichomes over the entire plant and the shape of the leaf blades with revolute margins. Diplusodon rosmarinifolius differs from it by its androecium with 15 stamens and the epicalyx segments ca. $0.5 \mathrm{~mm}$ long, spreading to deflexed.

\section{Diplusodon venosus T.B. Cavalc., $s p$. nov.}

Type:-BRAZIL. Goiás: Cavalcante, entroncamento Minaçú-Kalunga (Engenho Dois), km 5, 13³6’06”S, 47²8’29”W, 31 August 2004 (fl., fr.), Cavalcanti et al. 3534 (holotype CEN!; isotype SPF!). Figure 4.

Species characterized by the upper branches straw-colored, leaf blades 50-70 $\times 6-26 \mathrm{~mm}$, very distinct from bracts (1-4 mm wide), long bracteose inflorescence and flowers with 18-24 stamens.

Subshrubs $0.35-0.7 \mathrm{~m}$ tall, glabrescent, foliage lax. Branches slightly quadrangular and flattened, with an inconspicuous wing, the upper branches straw-colored, with minute and very inconspicuous trichomes to glabrous, internodes 3-4.5 cm long. Leaves decussate, rarely verticillate, not imbricate, erect, coriaceous, subsessile, not discolorous, not glaucous, not dark brown when dry, eucamptodromous to acrodromous; petiole $0.5-1 \mathrm{~mm}$ long; blades 50.5-70 $\times$ 6-26 mm, narrow-elliptic or narrow-lanceolate to wide-elliptic, base obtuse to acute, apex acute, slightly acuminate, margin plane, irregular, with minute and inconspicuous cilia, blades glabrescent to glabrous, trichomes when present slightly bulbose at the base, sparse, common on the abaxial surface; veins 2 or 3 along the midvein, very prominent; domatia present, inconspicuous. Synflorescence bracteose, triplobotryum to pleiobotryum type, lax; accessory branches absent, principal florescence of the botryum type, usually truncate, paraclades $5-25 \mathrm{~cm}$ long; bracts 15-30 × 1-4 mm, glabrous, linear to narrow-elliptic; flowers short-pedicelate, hypopodium $0.5-1 \mathrm{~mm}$ long, epipodium to $0.5 \mathrm{~mm}$ long; prophylls $4-4.2 \times 1.5-1.7 \mathrm{~mm}$, surpassing the middle of the floral tube, almost reaching the apex of the floral tube, narrow-elliptic to obovate, keeled, base retuse to acute, apex acute, margin plane; floral tube 4.5-5 mm long, funnel-shaped, glabrous; sepals 2-2.2 mm long, triangular, not deflexed, glabrous; epicalyx segments ca. $2 \mathrm{~mm}$ long, slightly dorso-ventrally compressed, spreading, glabrous, shorter than the sepals; corolla $3.5-4 \mathrm{~cm}$ in diam., lilac to rose-magenta, petals 13-19 $\times 7-10 \mathrm{~mm}$, obovate, apex obtuse; stamens 18-24, free portion of the filaments 6-6.5 $\mathrm{mm}$ long, slightly exserted; ovary $2-2.2 \times 2.2-3 \mathrm{~mm}$, obtrapezoidal, glabrous, style 7-10 mm long, ovules $22-42$. Capsules 4.5-5 × 4-4.5 mm, globose, glabrous; seeds ca. 31, 1.5-2.2 × 1.5-2.8 mm.

Distribution and ecology:-Diplusodon venosus is known only from the municipality of Cavalcante in the vicinity of the traditional community Kalunga. It inhabits cerrado and fields on sandy soil with sandstones at 919-1,030 m. Flowers from March to July; fruits April to September.

Etimology:- Specific epithet related to conspicuously veined leaves.

Paratypes:-BRAZIL. Goiás: Cavalcante, aldeia Kalunga, 6 March 2003 (fl.), Pastore \& Suganuma 444 (CEN!);

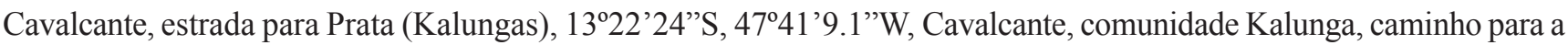
cachoeira Capivara, 20 April 2003, (fl.), Pastore et al. 471 (CEN!); Cavalcante, comunidade Kalunga, 20 April 2003, (fl.), Pastore et al. 473 (CEN!); Cavalcante, estrada para Prata (Kalungas), 13²2'24”'S, 4741'9.1'W, 14 April 2004 (fl.), Fonseca et al. 5095 (CEN!, HRB!, IBGE!).

Comments:-Diplusodon venosus is another unusual species of the genus from the mountains of Goiás. The upper branches are straw-colored, the bracteose inflorescence is long, broad and conspicuous, with distinct linear to narrowelliptic bracts different from the vegetative leaves, especially in size. The leaves are variable in width, ranging in shape from narrow-elliptic, narrow-lanceolate to wide-elliptic, but always with strongly prominent veins, also present on the bracts. Because of the bracteose inflorescence, the species resembles D. astictus Lourteig (1963: 6) and D. ramosissimus Pohl (1827: 151), which also occur in the region. However, D. astictus has upper branches wine-colored to chestnut, and larger flowers with 12 stamens. In D. ramosissimus the leaves have conspicuous domatia and the flowers have very short prophylls, not reaching the middle of the floral tube. 


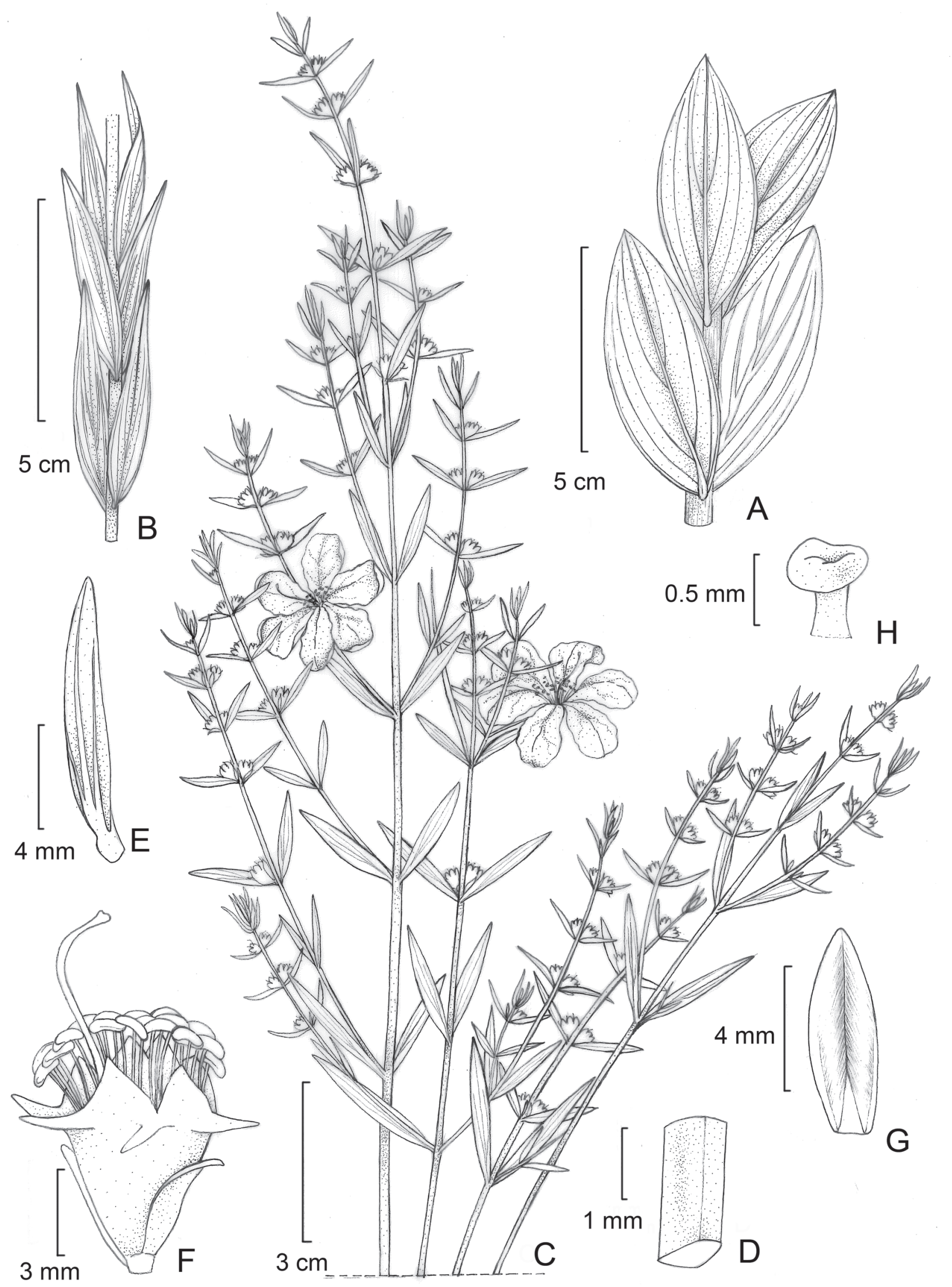

FIGURE 4. Diplusodon venosus (A from Pastore \& Suganuma 444; B-D from Pastore et al 473; E-H from Fonseca et al. 5095). A, section of vegetative branch with elliptic leaves. B, section of vegetative branch with narrow-elliptic leaves. C, branches with inflorescences. D, detail of a branch. E, bract, abaxial surface. F, flower with prophylls, without petals. G, prophyll, adaxial surface. H. stigma capitate. 
4. Diplusodon verruculosus T.B. Cavalc., sp. nov.

Type:-BRAZIL. Minas Gerais: Santana do Pirapama, Serra do Cipó, Capelão de São José, subida da Senhorinha, 1857’14”S, 4345’31”W, 6 March 2012 (fl., fr.), Zappi et al. 2733 (holotype CEN!, isotype SPF!). Figure 5.

Species characterized by small, narrow-triangular leaves, with strongly revolute margin and indumentum of short bulbous-based trichomes, flowers with long sepals and epicalyx segments that are distinctly ciliate with bulbous-based trichomes and the androecium has 6 stamens.
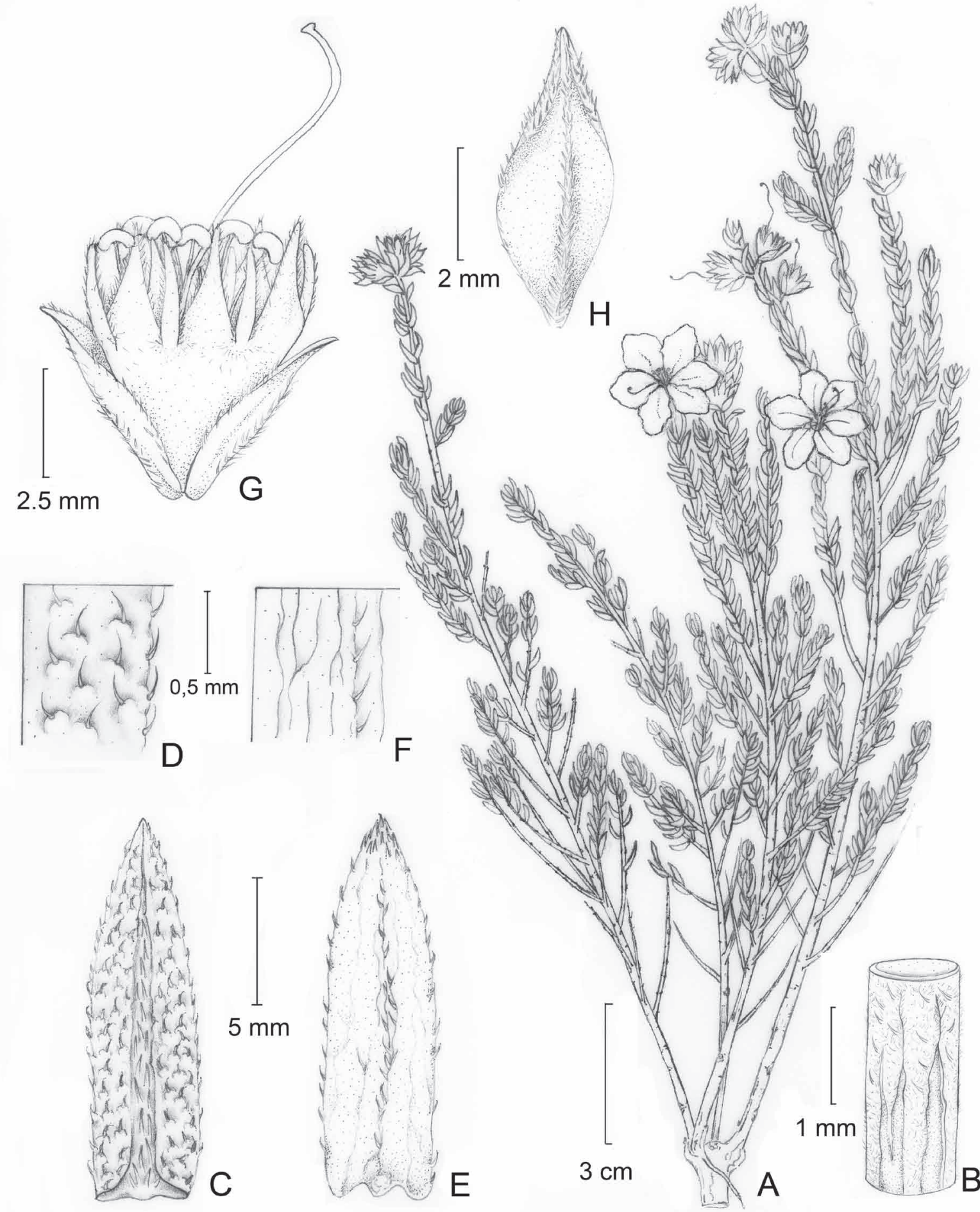

FIGURE 5. Diplusodon verruculosus (A-H from Zappi et al. 2733). A, habit. B, detail of a branch. C, leaf, abaxial surface. D, detail of leaf abaxial surface showing the bulbous-based trichomes; E, leaf, adaxial surface. F, detail of leaf adaxial surface. G, flower with prophylls, without petals. H, prophyll, adaxial surface. 
Subshrubs with a xylopodium, strongly branched from the base. Upper branches cylindrical, unwinged, strigose, internodes $0.8-2 \mathrm{~cm}$ long. Leaves decussate, slightly imbricate, erect, coriaceous, sessile, not discolorous, hyphodromous, blades 3-6 $\times 1-1.5 \mathrm{~mm}$, narrowly lanceolate, base retuse to cordate, apex acute, margin revolute to the midvein, strigose, blades covered by sparse bulbous-based trichomes giving the leaf surface a verrucose aspect; veins 1, only the midvein visible, hispid; domatia absent. Synflorescence frondose, diplobotryum type, congested; accessory branches absent, principal florescence truncated, paraclades 4-9 $\mathrm{mm}$ long; bracts similar to the vegetative leaves in shape and size; flowers sessile, concentrated at the apex of the paraclades; prophylls 5-5.5 $\times 2.8-3 \mathrm{~mm}$, surpassing the apex of the floral tube, elliptic, slightly keeled, margins subrevolute, base acute, with sparse, fine trichomes, almost glabrous; floral tube 3.5-3.8 mm long, funnel-shaped, with sparse, fine trichomes, almost glabrous; sepals 3.8-4 mm long, triangular, caudate, not deflexed, with sparse and fine trichomes, almost glabrous, strongly ciliate; epicalyx segments 3-3.2 mm long, narrowly triangular, erect, ciliate, the same size as or a little shorter than sepals; corolla ca. $2 \mathrm{~cm}$ in diam, deep rose, petals $9-10 \times 4.5-5 \mathrm{~mm}$; stamens 6 , free portion of the filaments $6-6.5 \mathrm{~mm}$ long, included within the sepals; ovary 2.5-2.7 × 2-2.6 mm, obconic, glabrous, style 10-11 mm long, ovules 18-20. Fruits not seen.

Distribution and ecology:-Known only from the municipality of Santana do Pirapama, Minas Gerais. The species grows in campo rupestres at 1,264-1,400 m. Flowers in February to March.

Etimology:- Specific epithet related to leaf surface covered with small wart-like outgrowths.

Paratype:-BRAZIL. Minas Gerais: Santana do Pirapama, Serra do Cipó, estrada São José da Cachoeira-Inhame, trilha da Senhorinha, 190'S, 4345'47’'W, 19 February 2007 (fl.), Zappi et al. 830 (ESA!, K!).

Comments:-Diplusodon verruculosus is characterized by small, narrowly triangular leaves, with strongly revolute margin and indumentum of short bulbous-based trichomes. The flowers have long sepals and epicalyx segments that are distinctly ciliate with bulbous-based trichomes, and the androecium has 6 stamens. It is vegetatively similar to $D$. saxatilis Lourteig (1989: 218), however, D. saxatilis is well defined by its hirsute branches, leaves and floral tube, and short (2.5-3 mm long) epicalyx segments that are distinctly shorter than the sepals and androecium with 12 stamens.

\section{Diplusodon vittatus T.B. Cavalc., $s p$. nov.}

Type:-BRAZIL. Goiás, Alto Paraíso de Goiás, povoado de São Jorge, na beira da estrada, 4 January 2003 (fl.), Pastore et al. 234, (holotype CEN!). Figure 6.

Species characterized by its xylopodium, ascending branches covered by white, sparse trichomes, narrow leaves with two prominent vein on each side of the midvein, epicalyx segments longer than the sepals and flowers with 18 stamens.

Subshrubs with a xylopodium. Upper branches subquadrangular, congested, unwinged, hirtellous to rarely pubescent, covered by white, sparse trichomes, internodes $0.7-1.1 \mathrm{~cm}$ long. Leaves decussate, not imbricate, suberect, coriaceous, petiolate, not discolorous, eucamptodromous; petiole ca. $1 \mathrm{~mm}$ long; blades $15-35 \times 1.5-6) \mathrm{mm}$, narrowlanceolate to narrow-elliptic, base acute, apex acute, margin revolute, adaxial surface sericeous to hirtellous with by white, fine trichomes; abaxial surface hirtellous to villous, with white trichomes; veins 2 on each side along the midvein, almost parallel, prominent on the abaxial surface; domatia present. Synflorescence frondose, diplobotryum spiciform type, lax; accessory branches absent, principal florescence 10-12 $\mathrm{mm}$ long, botryum spiciform type, paraclades 5-7 $\mathrm{mm}$ long; bracts similar to the vegetative leaves, except diminishing in size toward the apex of the branch, 15-25 $\times$ $1.5-3 \mathrm{~mm}$ wide, linear, margin revolute; flowers subsessile, hypopodium absent, epipodium ca. $0.5 \mathrm{~mm}$ long; prophylls ca. $5.5 \times 1.5 \mathrm{~mm}$, slightly surpassing the apex of the floral tube ca. $0.5 \mathrm{~mm}$, narrow-oblong, with 2 inconspicuous veins on each side of the midvein, base acute, apex acute, margin plane; floral tube ca. $5 \mathrm{~mm}$ long, funnel-shaped, sparsely covered with white, fine trichomes; sepals $2.8-3 \mathrm{~mm}$ long, triangular, not deflexed, not caudate, ciliate, covered by sparse, short, white, sparse trichomes, spreading; epicalyx segments 3-3.5 mm long, cylindrical, spreading, covered by sparse, short, white, sparse trichomes, spread; corolla ca. $4 \mathrm{~cm}$ in diam, lilac, petals ca. $21 \times 6 \mathrm{~cm}$; stamens 18 , free portion of the filaments ca. $8 \mathrm{~mm}$ long, exserted ca. $1 \mathrm{~mm}$; ovary ca. $2 \times 2.5 \mathrm{~mm}$, obovate, glabrous, style ca. $13.5 \mathrm{~mm}$ long, ovules ca. 21. Fruits not seen.

Distribution and ecology:-Diplusodon vittatus occurs in vegetation of campo limpo. Flowers in January.

Etimology:- Specific epithet related to the longitudinally striped adaxial leaf surface. 


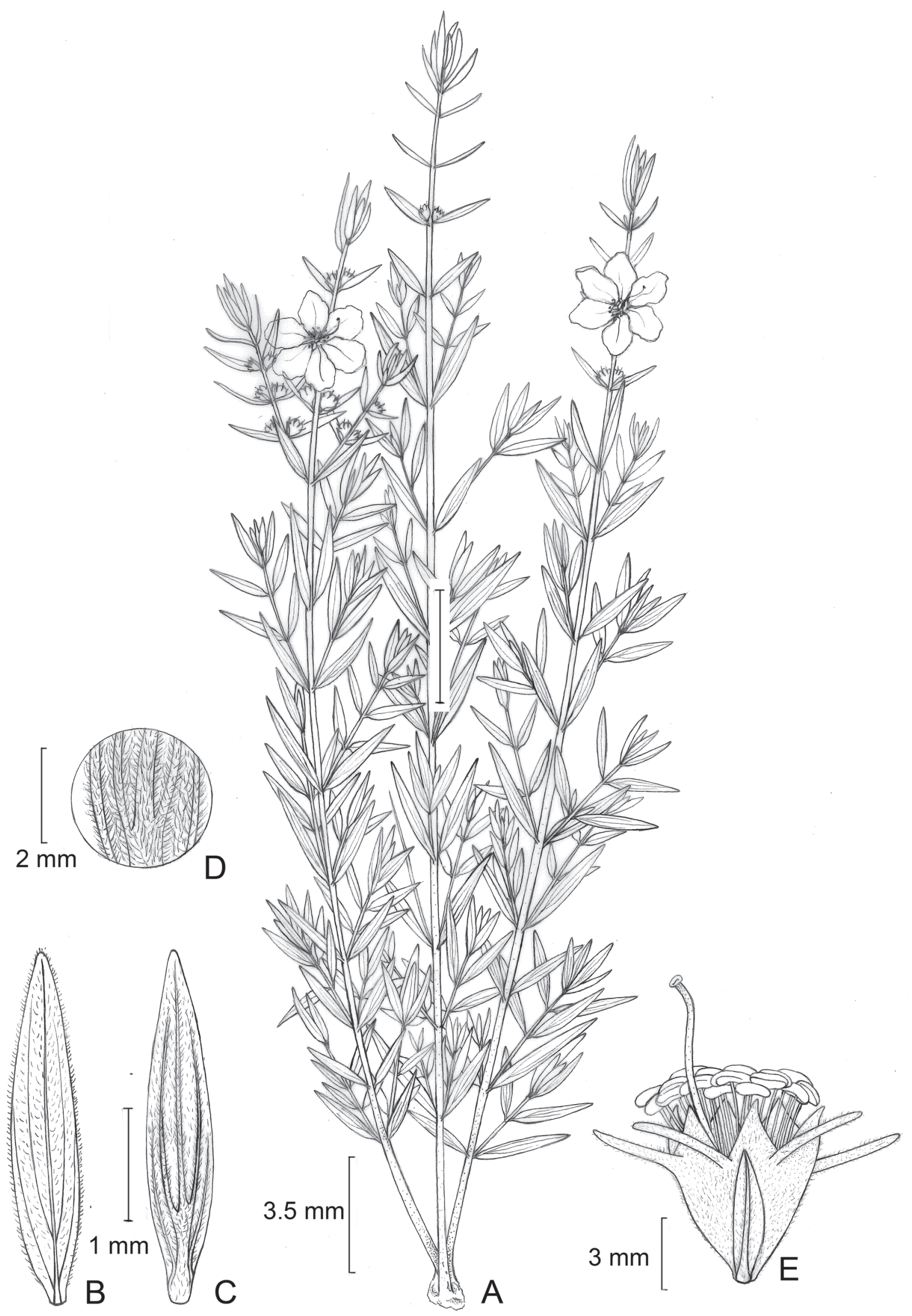

FIGURE 6. Diplusodon vittatus. (A-E from Pastore 234). A. habit. B, leaf, adaxial surface. C, leaf, abaxial surface. D, detail of leaf abaxial surface. E, flower with prophyll, without petals. 


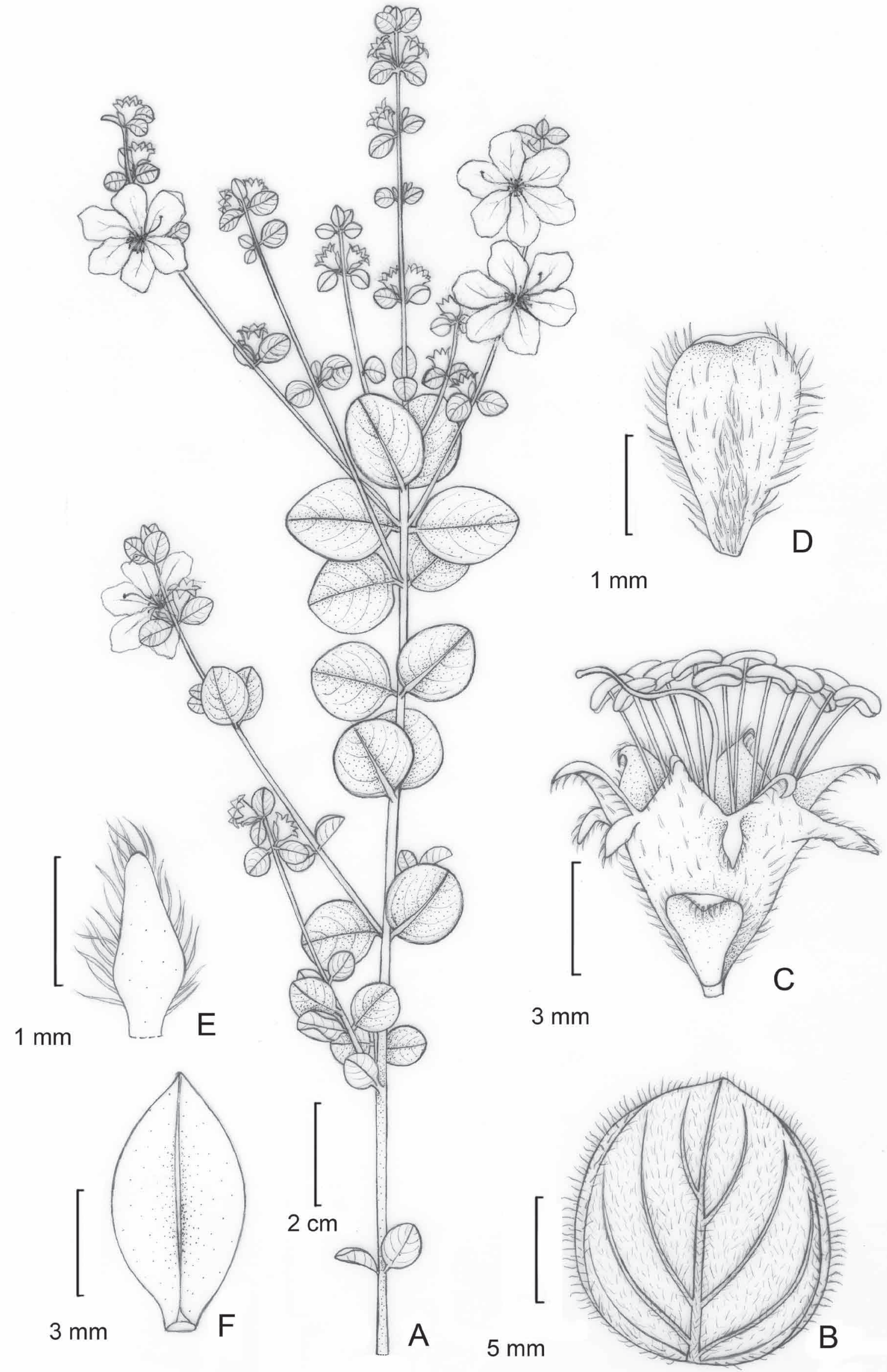

FIGURE 7. Diplusodon xiphodon (A-F from Harley \& Ribeiro, Jr. 55896). A, branch with inflorescences. B, leaf, abaxial surface. C, flower with prophyll, without petals. D, prophyll, adaxial surface. E, epicalyx segment. F. capsule. 
Comments:-Diplusodon vittatus is characterized by its habit with xylopodium and ascending branches covered by white, sparse trichomes, narrow leaves with one vein quite prominent on each side of the midvein, epicalyx segments $3 \mathrm{~mm}$ long and flowers with 18 stamens. Because of its narrow-lanceolate to narrow-elliptic with base and apex acute, it resembles $D$. macrodon Koehne (1877: 338). However, that species differs from it mainly by the presence of short stellate trichomes covering all the vegetative and floral parts and epicalyx segments much longer than the sepals (4-5 mm long).

\section{Diplusodon xiphodon T.B. Cavalc., sp. nov.}

Type:-BRAZIL. Bahia: Mucugê, Vale do Medronho, 13' ' S, 41211' W, 2 March 2009 (fl., fr.), Harley \& Ribeiro, Jr. 55896 (holotype, HUEFS!). Figure 7.

Shrubs, foliage lax. Upper branches cylindrical, unwinged, hirtellous, trichomes white, thick and sparse, internodes 1.5-4.5 cm long. Leaves decussate, not imbricate, patent to suberect, coriaceous, petiolate, slightly discolorous, dark brown when dry, acrodromous with supranumerary base to eucamptodromous; petiole 1-2 mm long; blades 10-20 $\times 7-15 \mathrm{~mm}$, orbicular to ovate, base obtuse to retuse, apex obtuse, margin subrevolute, hirtellous on both surfaces, adaxial surface gray-colored, abaxial surface rust-colored; veins 3 or 4 on each side along the midvein; domatia present, inconspicuous. Synflorescence bracteose, diplobotryum to triplobotryum type, lax; accessory branches absent, principal florescence ca. $9 \mathrm{~cm}$ long, paraclades 4-9 cm long, delicate; bracts 4-12 × 3-10 mm, orbicular; flowers subsessile, hypopodium ca. $1 \mathrm{~mm}$ long, epipodium 0-0.5 mm long; prophylls ca. $3.5 \times 2 \mathrm{~mm}$, reaching the middle of the floral tube, clavate to spathulate, unkeeled, apex obtuse, margin plane, with sparse, white, thick trichomes, strongly ciliate with thick trichomes; floral tube ca. $3.5 \mathrm{~mm}$ long, funnel-shaped with an attenuate base, sparsely covered with white, thick trichomes; sepals ca. $2 \mathrm{~mm}$ long, triangular, ciliate, slightly caudate, apex deflexed; epicalyx segments ca. $2 \mathrm{~mm}$ long, sword shape, flat, spreading, slightly shorter than sepals, glabrous, strongly ciliate with thick trichomes; corolla ca. $1.5 \mathrm{~cm}$ in diam., dark rose, petals ca. $6 \times 4 \mathrm{~mm}$, elliptic, apex obtuse; stamens 12, free portion of filaments ca. $7 \mathrm{~mm}$ long, exserted ca. $2 \mathrm{~mm}$; ovary ca. $2 \times 2 \mathrm{~mm}$, slightly rhomboid, glabrous, style $9-10 \mathrm{~mm}$ long, ovules ca. 7 . Capsules 4.5-5 × 3-3.5 mm, elliptic-fusiform, slightly stipitate, glabrous; seeds 5 or 6, 2.8-3 × 1.8-2 mm.

Distribution and ecology:-Known only from Mucugê, Bahia (Chapada Diamantina), growing in rocky-sandy soil. Flowers and fruits in March.

Etimology:- Specific epithet related to the sword-shaped epicalyx segments.

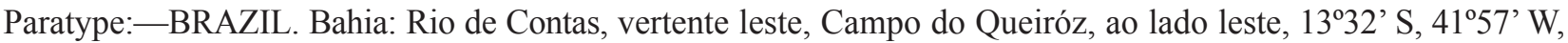
29 November 1988 (fl., fr.), Harley 26681 (CEN [2]!, CEPEC!, K!, SPF!).

Comments:-Diplusodon xiphodon is characterized by orbicular to ovate and slightly discolored leaves, delicate bracteose inflorescence with small flowers and orbicular bracts. Is similar to D. bahiensis T. B. Cavalcanti (2011: 30) because of its dark brown leaves when dry, hirtellous leaves and flowers and number leaf veins. The species differ mainly by $D$. bahiensis having frondose and congested inflorescence, with thick branches, larger flowers (floral tube $5-5.5 \mathrm{~mm}$ long) and prophylls longer $(6-6.5 \mathrm{~mm}$ long), reaching the apex of the floral tube or surpassing it until the base of the epicalyx segments.

\section{Acknowledgements}

The author thanks Glocimar Pereira da Silva, for his help with the field work in Brazil, and the large number of rich Diplusodon specimens that he has found during his field work. The illustrations were inked by Darli Nuza. The support of EMBRAPA and CNPq grant PQ/CNPQ 306762/2007-2 made possible the herbarium and field studies.

\section{References}

Cavalcanti, T.B. (1995) Revisão de Diplusodon Pohl (Lythraceae). Ph. D. thesis. Universidade de São Paulo, São Paulo, 505 pp.

Cavalcanti, T.B. (2007) Diversidade e distribuição em Diplusodon Pohl (Lythraceae). Fontqueria 55: 397-404. 
Cavalcanti, T.B. (2011) New taxa in Diplusodon (Lythraceae) from Brazil. Phytotaxa 38: 29-35.

Cavalcanti, T.B. (2015) Diplusodon. In: Jardim, B. do R. de J. (Ed.) Lista de Espécies da Flora do Brasil. Avaiable from: http://floradobrasil. jbrj.gov.br/jabot/floradobrasil/FB8776 (accessed 25 March 2015)

Cavalcanti, T.B. \& Graham, S.A. (2005) New taxa in Lythraceae from Latin America. Novon 15: 59-68.

Cavalcanti, T.B. \& Noronha, S.E. (2009) Lythraceae. In: Giulietti, A.M., Rapini, A., Andrade, M.J.G., Queiróz, L.P. \& Silva, J.M.C. (Eds.) Plantas raras do Brasil. Conservation International, pp. 243-251.

Cavalcanti, T.B., Fernadez, E.P., Xavier, R.A., Prieto, P.V., Barros, F.S.M. \& Maurenza, D. (2013) Lythraceae. In: Miguel, d’Á. de M. (Ed.) Livro Vermelho da Flora do Brasil. Andrea Jakobsson Editora, Rio de Janeiro, pp. 630-638.

Inglis, P.W., Azevedo, V.C.R., Ciampi, A.Y. \& Cavalcanti, T.B. (2009) A multi-gene phylogeny of the Brazilian Cerrado genus Diplusodon Pohl (Lythraceae). Resumos do 55 Congresso Brasileiro de Genética 1: 191.

Koehne, E. (1877) Lythraceae. Flora Brasiliensis 13 (2): 186-370.

Koehne, E. (1903) Lythraceae. Das Pflanzenreich Regni Vegetabilis Conspectus 4 (216): 326.

Lourteig, A. (1989) Lythraceae Austroamericanae. Addenda et corrigenda III. Bradea 5 (19): 205-241.

Pohl, J.E. (1827) Diplusodon. Neue Brazilianische Gesellschaft. Flora 10 (1): 150-152.

Saint-Hilaire, A. (1833) Flora Brasiliae Meridionalis 3. Parisiis, pp. 1-160. 